\title{
Effect of Substrates on the Production of Banana Rejects by the Fragmentation Planting Method (FPM) in Central African Republic
}

\section{Touckia Gorgon Igor ${ }^{1 *}$, Elian Dieubeni Hubert ${ }^{1}$, Yongo Olga Diane ${ }^{2}$, Bobere Jesus Trésor ${ }^{1}$ and Kokou Kouami ${ }^{3}$}

${ }^{1}$ High Institute of Rural Development, University of Bangui, Central African Republic

${ }^{2}$ Plant and Fungal Biodiversity Laboratory, Faculty of Science, University of Bangui, Central African Republic

${ }^{3}$ Forest Research Laboratory, Faculty of Science, University of Lomé, Togo

*Corresponding Author: Touckia Gorgon Igor, High Institute of Rural Development, University of Bangui, Central African Republic.
Received: May 15, 2021

Published: June 09, 2021

(C) All rights are reserved by Touckia Gorgon Igor., et al.

\begin{abstract}
In the Central African Republic, although its cultivation occupies an important place in the rural economy, plantain production remains insufficient due to the unavailability of good quality plant material. The objective of the present study is to test the effect of substrates on the production of banana offshoots by the Fragments Planting Method (FPM) of the stem by comparing different varieties in order to identify the one that responds better to this method. Two local varieties and one variety from the African Center for Banana and Plantain Research (CARBAP) were produced in the nursery. The propagator used is composed of three racks each filled with one or a mixture of substrate that are, sawdust, sand and fine sawdust of white wood, fine sand with a proportion mixed with coffee parchment. The effect of the variety and the substrate on the different parameters of growth of the seedlings was appreciated thanks to the analysis of variance (ANOVA) with two criteria of classification with the Software R version. The results show that the variety Batar of CARBAP, presents a better performance compared to the others. Regarding the substrate, the parchment+sand mixture gives more relevant results than the other substrates.
\end{abstract}

Keywords: PIF Method; Banana; Substrate; Central African Republic

\section{Introduction}

Dessert bananas and plantains are among the major food crops in the human diet as they are grown in more than 100 countries in the tropical and subtropical regions of the world [1,2]. They provide one of the main staple foods to millions of people and play an important role in the social structure of many rural communities [3]. They are ranked fourth in the list of important foodstuffs after rice, wheat and corn. Its global production amounts to 74 million tons per year [4]. As a food crop, bananas are particularly important because they produce a good quality food throughout the year and can be adapted to a wide variety of cropping systems [5].
In the Central African Republic, this crop occupies an important place in the rural economy with an annual production of 129129 tons [6]. With traditional cultivation practices, banana production in the zones remains low (10 tons/ha). However, there is potential for plantain production in the Central African Republic, as agricultural land is available, climatic conditions are favorable and demand is constantly increasing. Despite its ability to adapt to a variety of ecosystems and its high potential for producing edible dry matter, plantain remains a marginal crop compared to its potential.

Plantain farms are insufficient because of the unavailability of good quality plant material [7]. The parasitic pressure on the crop 
reinforces the use of poor rejects, thus reducing the maximum exploitation period to less than two years. All this does not remunerate the effort made by the farmers, leading to their discouragement [8].

Fortunately, several intensive production techniques have been developed, including in vitro cultivation, which has remained the prerogative of research centers, and planting from stem fragments (PIF), a technique that is enjoying undeniable success with farmers because it is easily reproducible. From one offshoot, it is possible to obtain 10 to 50 plantain plants depending on the variety and the experience of the manipulator [9].

Despite its importance, very few studies have been carried out in the Central African Republic on the production of planting material for the expansion of cultivable areas and the organization of the dessert banana and plantain sector.

\section{Objective of the Study}

Thus, the general objective of this work is to compare the effect of three (3) types of substrates on the growth parameters of three banana varieties by the method of PIF at the nursery stage.

\section{Aim of the Study}

More specifically, the aim is to:

- $\quad$ Test the effect of different substrates on the production of banana shoots by the FIP method;

- Evaluate the performance of each banana variety.

\section{Materials and Methods}

Study site

High institute of rural development

The trials were conducted at the High Institute of Rural Development (HIRD) site in Mbaïki in the southwestern part of the country in a forested area (Figure 1).

\section{Climate and soil}

The climate of the study site is of the Guinean forest type with two alternating seasons: a rainy season from March to mid-December and a dry season from January to February. The average annual maximum temperature is $30.65^{\circ} \mathrm{C}$. The differences between the average minimum and maximum temperatures are moderate $\left(11.44^{\circ} \mathrm{C}\right)$. The average annual rainfall is around $1600 \mathrm{~mm} /$ year and the soil has a sandy clay texture [10].

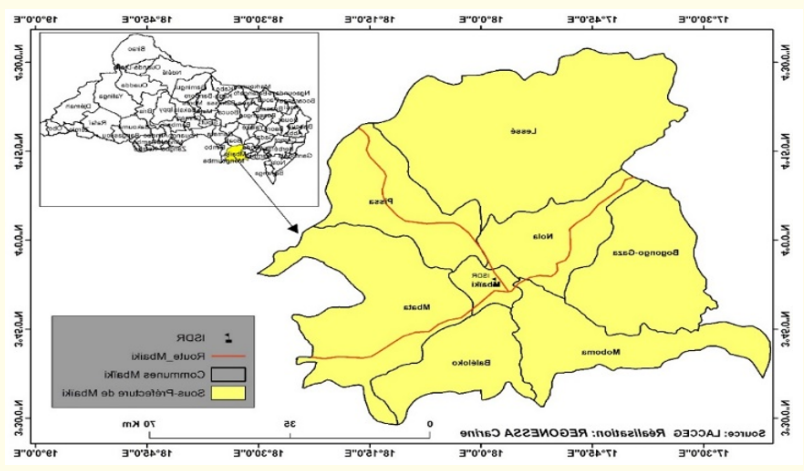

Figure 1: location of the experimental site.

Vegetation

The vegetation of the town of Mbaïki has the same characteristics as that of southwestern CAR. This forest massif has a very high forest diversity and a range of forest from lowland dense rainforest south of the $4^{\text {th }}$ parallel to dense dry forest north of the $4^{\text {th }}$ parallel interspersed with savannahs. This vegetation is made up of reworked forest, secondarized with Triplochiton scleroxylon and Terminalia superba [11].

Main steps in the production of fragments of stems (FIP)

The FIP technique aims at injuring the meristem without killing it, to unbalance it in order to promote a rapid development of all buds at the same time. For this purpose, shoots taken from the field were used. Dehulling, which consists in removing the sheaths, generally 3 to 5 leaf sheaths, allowed to obtain the pseudo-stem which is reduced to 1 or $2 \mathrm{~mm}$ above the last visible node of the stem. The trimming and dehusking of the shoots allowed to obtain explants. These explants were then placed in the germplasm upright and side by side, with the incised part of the pseudo-stem facing upwards. The density per $\mathrm{m}^{2}$ depends on the size of the explants used.

Once the explants were placed in the sawdust, they were covered by a transparent plastic film placed at a minimum distance of $60 \mathrm{~cm}$ height. The first watering of the germinator was done one day after seeding and then with a frequency of two to three times a week. 


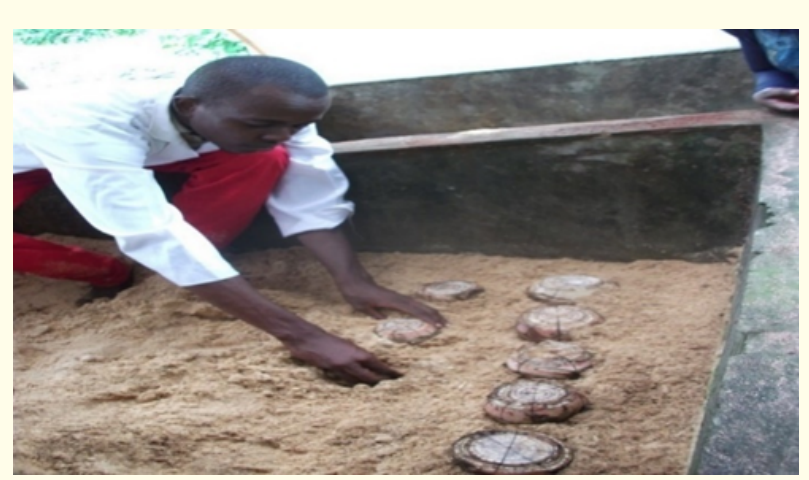

Figure 2: Seeding of bulbs in the propagator.

\section{Growth monitoring, plant maintenance}

Watering started three days after sowing, with a frequency of twice a day, morning and afternoon, and continued to stop temporarily on the fourth day in order to prevent the explants from rotting. It was necessary to wait one week to resume with watering morning and evening. As the young seedlings do not support competition with weeds, weeding was done regularly.

Weaning of the seedlings occurred 30 to 40 days after seeding. The young plants having 3 to 5 leaves were carefully detached with a scalpel blade or a sharp knife. Then there was transplanting in bags and acclimatization under shade. The seedlings are transplanted with all their roots in black polyethylene bags, perforated, of variable size depending on the duration of the nursery.

The filled bags are then stored in a bed, still waterlogged at the time of transplanting. The seedling is introduced inside the hole, and the ground is packed slightly without compacting and only the bulb must be buried. At the end of the transplanting, the young seedlings were watered abundantly. The transplanted plants were then placed under a shade, which provided an ideal acclimatization temperature of $25-27 \mathrm{C}$.

\section{Parameters evaluated}

The parameters that were measured during the experiment were: emergence rate, diameter at the neck of the seedlings, number of leaves, length and width of the leaves, height of the seedlings, number of seedlings per shoot and number of roots.
Data analysis

The effect of variety and substrate on the different parameters of seedling growth was assessed using the two-criteria analysis of variance (ANOVA) classification with $\mathrm{R}$ Software version 3.1.3. The Shapiro-Wilk test was used to verify the normality of the data and the different tests are validated at the $5 \%$ threshold. The different graphs were realized with the Excel spreadsheet.

\section{Results}

\section{Emergence rate of seedlings}

The different varieties used in the study showed a better emergence rate (80 to $100 \%$ ) depending on the different types of substrates used. The nature of the substrate influences the duration and the emergence rate of the seedlings. The sand + parchment mixture favored a faster emergence with an emergence rate of $100 \%$ at the fourteenth day (14 days). With respect to root emergence and leaf emergence, the sand + parchment mixture always shows the best results. No variability was observed according to the different varieties used (Table 1).

\begin{tabular}{|c|c|c|c|c|c|}
\hline Substrat & Variety & $\begin{array}{c}\text { Emergence } \\
\text { time } \%\end{array}$ & $\begin{array}{c}\text { Emer- } \\
\text { gence } \\
\text { Root }\end{array}$ & $\begin{array}{c}\text { Root } \\
\text { emission } \\
\text { stage }\end{array}$ & $\begin{array}{c}\text { 2 leaf } \\
\text { stage }\end{array}$ \\
\hline \multirow{2}{*}{$\begin{array}{c}\text { Sciure }+ \\
\text { saber }\end{array}$} & Batar & 21 days & $100 \%$ & 10 days & 12 days \\
\cline { 2 - 6 } & Sékélé & 21 days & $90 \%$ & 10 days & 12 days \\
\cline { 2 - 6 } & Gbongalet & 21 days & $90 \%$ & 10 days & 12 days \\
\hline \multirow{2}{*}{$\begin{array}{c}\text { Sabre }+ \\
\text { patch }\end{array}$} & Batar & 21 days & $100 \%$ & 7 days & 8 days \\
\cline { 2 - 6 } & Sékélé & 21 days & $100 \%$ & 7 days & 8 days \\
\cline { 2 - 6 } & Gbongalet & 21 days & $100 \%$ & 7 days & 8 days \\
\hline \multirow{2}{*}{ Sciure } & Batar & 21 days & $80 \%$ & 14 days & 12 days \\
\cline { 2 - 6 } & Sékélé & 21 days & $80 \%$ & 14 days & 12 days \\
\cline { 2 - 6 } & Gbongalet & 21 days & $80 \%$ & 14 days & 12 days \\
\hline
\end{tabular}

Table 1: Emergence and growth parameters at the juvenile stage.

Number of seedlings per plant

The parchment+sand substrate produced a slightly higher number of seedlings than the sawdust-sand substrate (Figure 3). The analysis of variance carried out on the number of seedlings per plant shows that the difference observed is significant $(\mathrm{p}=$ 0.00000118). According to varieties, "Batar" is the one that gives 
more seedlings per foot this observed difference is significant $(\mathrm{p}$ $=0.002092$ ).

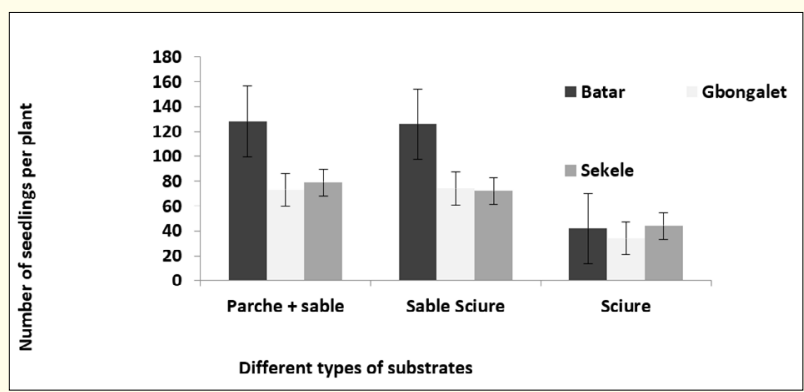

Figure 3: Number of seedlings per plant.

\section{Diameter of the collar}

Figure 4 below, shows the diameter of the collar considered according to the substrates. The simple sawdust substrate gives seedlings with a slightly higher diameter. The difference observed from the statistical point of view is not significant ( $\mathrm{P}$-value $=0.7924)$. According to the varieties, the Gbongalé variety has a slightly high diameter $(\mathrm{P}$-value $=0.2658)$.

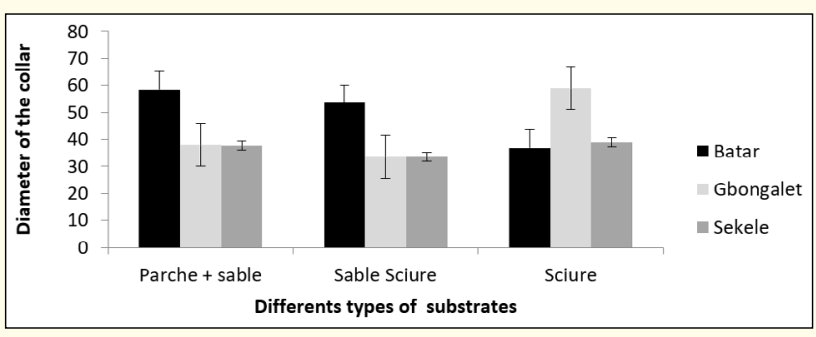

Figure 4: Diameter of the collar.

\section{Number of leaves}

The number of leaves considered according to the substrates is higher on the sawdust + sand substrate (Figure 5). The difference observed, from a statistical point of view, is significant $(\mathrm{P}$-value $=$ 0.1837). According to the varieties, the variety Batar has the highest number of leaves (P-value $=0.003072$ ).

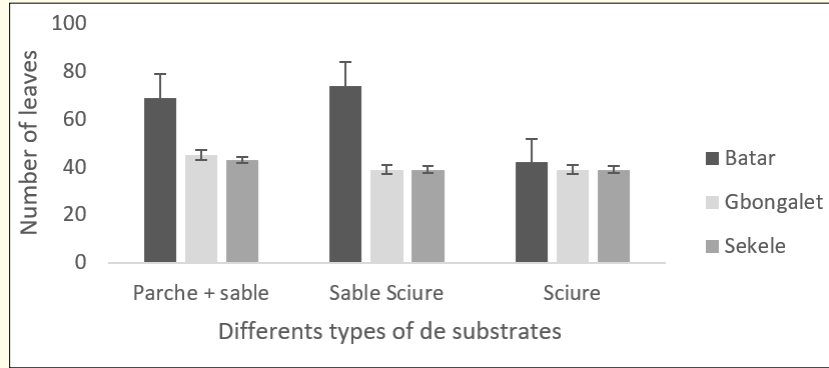

Figure 5: Number of leaves.

Leaf blade length

The lengths of the blades considered according to the substrates present a significant difference (P-value $=0.1544)$. According to the varieties the difference observed is not significant $(\mathrm{P}$-value $=$ 0.09961). The variety Batar seems to be the best. The substrate Parche+sand favors the obtention of seedlings with longer leaves (Figure 6).

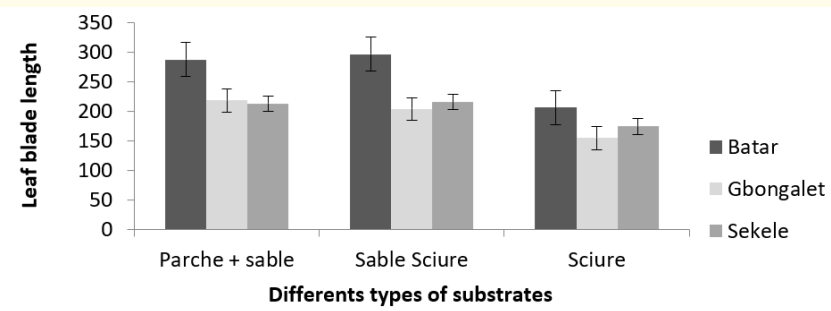

Figure 6: Leaf blade length.

Blade width

According to the substrates, no variation was observed in the width of the leaf blades of the seedlings (P-value $=0.04036)$. Depending on the variety, Batar has a wider blade width, although the difference observed is not significant (Figure 7).

\section{Number of roots}

The number of roots as a function of the substrate is higher in the case of simple sawdust (Figure 8). From a statistical point of 
view this observed difference is not significant $(\mathrm{P}$-value $=0.02309)$. The Sekele species seems to have a slightly higher number of roots, although statistically this difference is not significant $(\mathrm{P}$-value $=$ 0.2129). The sawdust substrate produces many roots.

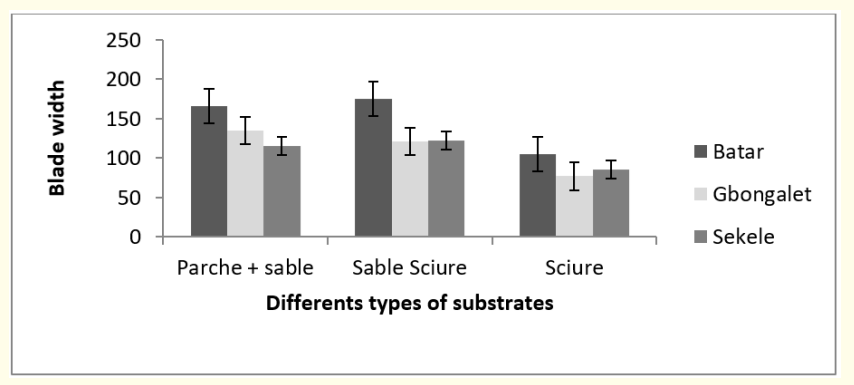

Figure 7: Blade width.

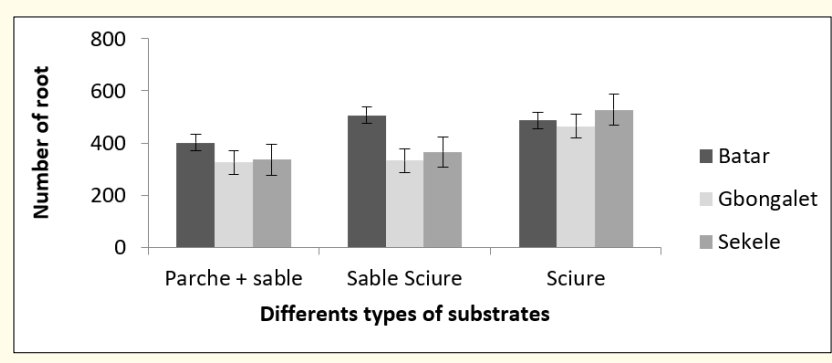

Figure 8: Number of roots.

\section{Stem height}

The heights of the seedlings considered according to substrates do not show any variability). However, depending on the variety, a significant difference was observed with regard to the Batar variety, which had a better height (P-value $=0.0008607$ ) than the others (Figure 9).

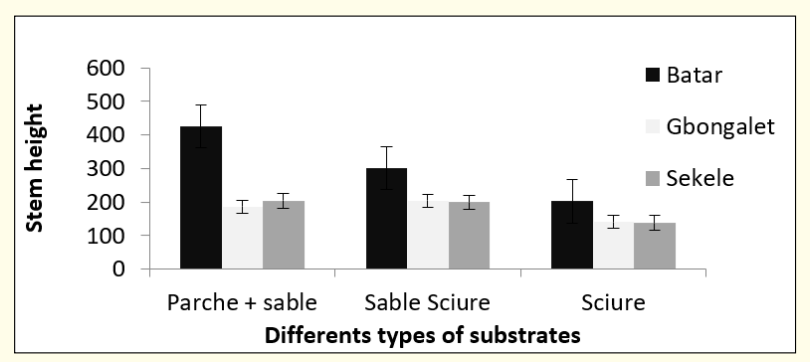

Figure 9: Stem height.

\section{Discussion}

The result on the recovery time of the different varieties indicates that all the varieties used are of good quality because their recovery time is around 3 weeks. Similar results were obtained by [12] in the Republic of Congo and by [13] in the Democratic Republic of Congo with local varieties. With regard to growth at the juvenile stage, the results show that the nature of the substrate influences the duration and the rate of emergence of the seedlings. However, no difference was observed between varieties [9] in Côte d'Ivoire, indicating that the FIP technique is a means for mass production of live plantain seedlings. However, the development, growth and yield of FIP plants are influenced by many factors including the type of substrate used [14] also state that the development, growth and yield of BIP plants are influenced by many factors including the type of substrate used during acclimation.

The sand + parchment mixture favors a faster emergence with a very high percentage (100\%). Root and leaf emergence was also better with this type of substrate, although no variability was observed with different varieties used. Studies carried out by the African Banana and Plantain Research Center (CARBAP) have shown that the use of a mixture of materials favoring the supply of nutrients and aeration of the substrate is necessary for the development of the fragile root system of the vivo plants [14].

The Batar variety produces seedlings that are taller than the Gbongalé variety, which produces seedlings with a larger diameter, and the Sékélé variety, which produces many more roots. Indeed, the Batar variety, which seems to have better growth, is a variety created by CARBAP. Similar studies in some African countries, notably Cameroon, Benin and the Democratic Republic of Congo, show that the varieties developed by CARBAP perform better than local varieties [12].

The results obtained in this study are convincing, although the sowing was done in August, three months after the dry season and the PIF technique is recommended in the dry season because of the heat that activates the emergence of seedlings and the number of seedlings per foot [9]. A variability is observed between the number of leaves, the number of roots, the number of seedlings per foot, the height of the seedlings according to the varieties as well as the types of substrates. According to [15], confirmed by [16], the study of the varietal response of banana cultivars to the FIP technique shows that not all cultivars reacted in the same way. 


\section{Conclusion}

The study allowed to analyze the potentialities of banana seed production by the FIP method. The variety Batar, developed by CARBAP, showed better performance than Gbongale and Sékèlè, which are local varieties, in terms of number of plants per explant, plant height and blade width. Even if the observed difference is statistically significant, the Gbongalé variety gives seedlings with larger leaves and a larger diameter. The Sékélé variety produces seedlings with a greater number of roots. As regards the substrate, the mixture parchment+sand gives more interesting results compared to the other substrates. These results show that the Batar variety and the parchment+sand substrate can be very interesting for a sustainable production. Although there is a difference between the growth parameters according to substrates and varieties, the three substrates and varieties used in this study present potentialities for the production of banana seeds by the technique of seedlings from fragments.

\section{Bibliography}

1. Bakelana BK et Muyunga T. "La production de bananes et de bananes plantain en République Démocratique du Congo". In Les productions bananières : un enjeu économique majeur pour la sécurité alimentaire Pioq, C., Fouré, E. and Frison, E.A. (eds). Bananas and Food Security : International symposium. INIBAP (1998): 103-115.

2. Temple L., et al. "Enjeux du plantain au Cameroun et amélioration des systèmes de production par une recherche-action participative". In Acorbat. Memorias XV réunion. Realizada en Cartagena de Indias, Colombia. 27 de octobre al 02 novembre 2002; Sesión cartel transferencia de tecnología, CARBAP, S/C CIRAD BP 2572 Yaoundé (2002): 593-601.

3. Lassoudiere A. "Le bananier et sa culture". Quae, Versailles (2007): 383.

4. Arias P., et al. "L'économie mondiale de la banana". (19852002), FAO, Rome, 113.

5. Mialoundama Bakouétila GF., et al. "Production de la banane (Musa sp.) dans le district de Mouyondzi, République du Congo". Journal of Animal and Plant Sciences 30.1 (2016): 47144726.

6. FAO (Food and Agriculture Organization). "What is Agro-biodiversity?" (2008).

7. Ngo-Samnick E. "Production Améliorée du Bananier Plantain". Pro-Agro (Engineers Without Borders, Cameroon (ISF Cameroun)/Technical Centre for Agricultural and Rural Co-operation (CTA), Wageningen, The Netherlands (2011).
8. Koua Tano C M. "Effets de différents types de substrats sur la croissance des vivoplants de bananiers plantain musa sp en phase d'acclimatation Mémoire de Master de Biologie et Protection des végétaux". UFR des Sciences de la Nature, Université de Côte d'Ivoire (2014): 57.

9. Kwa M. "Activation de bourgeons latents et utilisation de fragments de tige du bananier pour la propagation en masse de plants en conditions horticoles in vivo". Fruits 58 (2003): 315328.

10. Boulvert Y. "Carte phytogéographique de la République centrafricaine". ORSTOM. Notice Explicative, 104, Paris (1986): 131.

11. "Atlas de la République Centrafricaine". Edition Enfance et Paix, Kinshasa (2008): 169.

12. Ognagna A., et al. "Etude de la production des plants de bananiers et plantains (Musa (spp.) par la technique des PIF au Congo: Effets des substratssur la croissance et le développement des plants en pépinière". International Journal of Neglected and Underutilized Species (2016): 242-256.

13. Bangata BM., et al. "Évaluation du potentiel prolifératif de six cultivars de bananier (cv. AAB, ABB, et AAA) par macropropagation en République Démocratique du Congo". Journal of Applied Biosciences 127 (2018): 12770-12784.

14. Sadomi L., et al. "Comparaison de l'efficacité de deux méthodes de multiplication rapide de plants de bananier à partir de l'étude des caractéristiques agronomiques d'un hybride de bananier plantain (Musa spp.)". Fruits 65.1 (2010).

15. Efanden C., et al. "Partenariat en sélection participative sur bananiers plantains : l'expérience du Centre africain de recherches sur bananiers et plantains au Cameroun". Partenaires pour construire des projets de sélection participative, Mars 2005, Cotonou, Benin (2005): 153-173.

16. Lepoint P., et al. "Macropropagation of Musa spp". In Burundi: A Preliminary Study. In : Guy Blomme, Bernard Vanlauwe and Piet van Asten (Ed.), Banana Systems in the Humid Highlands of Sub-Saharan Africa, Enhancing Resilience and Productivity, International conference organized by the Consortium for Improving Agriculture-based Livelihoods in Central Africa (CIALCA), Kigali, Rwanda, from 24 to 27 October (2011): 58-65.

Volume 5 Issue 7 July 2021

(C) All rights are reserved by Touckia Gorgon Igor., et al. 